\title{
Konsep Penanaman Modal Sebagai Upaya Mestimulasi Peningkatan Perekonomian Indonesia
}

\author{
oleh : \\ Agus Saiful Abib, Endah Pujiastuti, Tri Mulyani. \\ Fakultas Hukum Universitas Semarang \\ agus_saifulabib@yahoo.com, endahpujiastuti@gmail.com,tri_mulyani@gmail.com
}

\begin{abstract}
ASBTRAK
Pelaksanaan pembangunan membutuhkan biaya yang sangat besar, oleh karena membutuhkan support penuh dari penanam modal khususnya penanam modal asing. Penelitian ini akan mengakaji mengenai perkembangan penanaman modal dari era orde lama, orde baru dan orde revormasi serta kendala atau hambatan serta solusi yang diberikan dalam meningkatkan penanaman modal di Indonesia. Metode pendekatan yang digunakan adalah yuridis normatif dengan mempelajari azas-azas hukum yang berasal dari bahan-bahan kepustakaan. Perkembangan penanaman modal era orde lama belum ada perkembangan, sedangkan era orde pencapaian terbaik PMA 1997 dengan 33.788 .8 miliar US\$ dan PMDN Rp. 119,877,2 triliun. Orde reformasi pencapaian terbaik PMA 2015 dengan mencatatkan 29,275.9 miliar US\$ dan PMDN 2016 sebanyak Rp. 216,230 triliun triliun. Kendala yang dihadapi Indonesia dalam penanaman modal datang dari internal maupun eksternal. Solusi penanaman dengan kepastian hukum, penyediaan lahan, keamanan dan stabilitas politik, tenaga kerja, perijinan yang cepat, infrastruktur memadai, tersedianya pasar market.
\end{abstract}

Kata kunci : Penanaman Modal; Perekonomian; Indonesia;

\begin{abstract}
Implementation of development requires enormous costs, and therefore require the full support of investors, especially foreign investors. This study will mengakaji about the development of the investments of the era of the old order, the new order and the order revormasi well as obstacles or barriers and the solutions given in increasing investments in Indonesia. The method used is a normative juridical by studying the principles of the law derived from the materials library. The development capital investment era of the old order has been no progress, while the order era PMA 1997 with the best achievement 33.788 .8 billion US \$ and foreign Rp. 119,877,2 trillion. Order of the best achievements of reform PMA 2015 with a record 29,275.9 billion US \$ and foreign, in 2016 as much as Rp. 216.230 trillion trillion. Constraints faced by Indonesia in capital investment comes from both internal and external. Solution planting with legal certainty, the provision of land, security and political stability, labor, permits rapid, adequate infrastructure, market availability market.
\end{abstract}

Keywords: Investment; Economy; Indonesia;

\subsection{Latar Belakang Penelitian}


Penanaman modal merupakan roda penggerak ekonomi suatu negara yang membutuhkan modal besar dan cepat guna meningkatkan pertumbuhan ekonomi secara nasional dan berkelanjutan. Besarnya modal yang dibutuhkan serta keterbatasan modal yang dimiliki negara membuat Indonesia sulit melaksanakan pembangunan nasional, oleh karena itu pemerintah mengambil kebijakan berupa penambahan utang luar negeri dan membuka kran investasi dengan mengundang penanam modal dalam negeri maupun penanam modal asing untuk menanamkan modalnya di Indonesia.

Keterbukaan penanaman modal di Indonesia dimulai sejak orde baru dengan membuat kebijakan berupa terbukanya penanaman modal baik asing maupun dalam negeri dengan diterbitkannya UU Nomor 1 Tahun 1967 tentang Penanaman Modal Asing dan UU Nomor 6 Tahun 1968 tentang Penanaman Modal Dalam Negeri. Eksistensi undang-undang tersebut dirasa tidak mampu mengakomodir perkembangan perekonomian global, sehingga diperlukan aturan yang bersifat komprehensif guna menciptakan iklim penanaman modal yang kondusif, memberikan kepastian hukum, keadilan, dan efisien dengan tetap memperhatikan kepentingan ekonomi nasional. Hukum penanaman modal memiliki peran yang sangat signifikan dalam menciptakan iklim investasi yang kondusif guna meningkatkan penanaman modal bagi negara penerima investasi. Peranan hukum dalam menciptakan iklim investasi yang kondusif merupakan persyaratan mutlak, mengingat investor asing tidak akan melakukan investasi di tempat yang tidak memiliki kepatian hukum (legal certainty) yang dapat menimbulkan risiko hukum (regulatory risk atau legal risk) yang sangat tinggi. ${ }^{1}$ Oleh karena itu UU Nomor 1 Tahun 1967 tentang Penanaman Modal Asing dan UU Nomor 6 Tahun 1968 tentang Penanaman Modal Dalam Negeri dicabut dan dinyatakan tidak berlaku serta diganti UU Nomor 25 Tahun 2007 tentang Penanaman Modal.

UU Nomor 25 Tahun 2007 tentang Penanaman Modal mengkatagorikan penanam modal menjadi 2 (dua) yaitu penanam modal dalam negeri dan penanam modal asing. Keberadaan penanam modal dalam negeri maupun asing pada dasarnya sama - sama memberikan dampak positif bagi perekonomian negara penerima investasi, tetapi ada pula yang tidak setuju akan keberadaan penanam modal asing yang dirasa keberadaannya dianggap sebagai ancaman. Terlepas dari pro maupun kontra penanaman modal asing, ternyata keberadaannya membawa dampak positif, hal ini disebabkan para penanam modal asing membawa modal besar, ilmu pengetahuan dan teknologi modern memberikan banyak manfaat bagi negara berkembang maupun tertinggal sebagai negara penerima investasi (house country), oleh karenanya negara penerima investasi (house country) berlomba-lomba menarik penanam modal dari penjuru dunia. Sebagaimana dikemukan Hendrik Budi Untung²:

\footnotetext{
${ }^{1}$ David Kuripan, Aspek Hukum Penanaman Modal Asing Di Indonesia, Kencana Prenada Media Group, Jakarta, 2013, halaman 6.

${ }^{2}$ Hendrik Budi Untung, Hukum Investasi, Sinar Grafika, Jakarta, 2013, halaman 41-42.
} 
Manfaat yang dimaksud yakni kehadiran investor asing dapat menyerap tenaga kerja di negara penerima modal, dapat menciptakan demand bagi produk dalam negeri sebagai bahan baku, menambah devisa apalagi investor asing yang berorientasi ekspor, dapat menambah penghasilan negara dari sektor pajak, adanya alih teknologi (transfer of technologi) maupun alih pengetahuan (transfer of know how).

Indonesia memiliki potensi sumber daya alam yang besar dan perlu dikembangkan akan tetapi belum dikelola secara maksimal. Hal ini merupakan tantangan sekaligus kesempatan bagi pemerintah untuk mengolah potensi yang tersedia menjadi ekonomi riil serta meningkatkan penanaman modal yang bermanfaat untuk kesejahteraan masyarakat. Oleh karena itu dalam rangka meningkatkan kegiatan penanaman modal di Indonesia dan dalam rangka pelaksanaan komitmen Indonesia dalam kaitannya dengan Association of Southeast Asean Nation/ASEAN Economic Community (AEC) pada tanggal 23 April 2014 pemerintah melalui Peraturan Presiden No. 39 Tahun 2014 tentang Daftar Bidang Usaha Yang Tertutup Dan Bidang Usaha Yang Terbuka Dengan Persyaratan Di Bidang Penanaman Modal memberikan gambaran secara komprehensif tentang bidang usaha yang terbuka dengan syarat dan bidang usaha tertutup guna memberikan kemudahan pemahaman bagi calon penanam modal untuk melakukan kegiatan penanaman modal di Indonesia.

Pernanaman modal adalah segala bentuk kegiatan menanam modal, baik oleh penanam modal dalam negeri maupun penanam modal asing untuk melakukan usaha di wilayah negara Republik Indonesia. Oleh karena itu pelaksanaan penanaman modal dapat dilaksanakan oleh penanam modal dalam negeri maupun penanam modal asing yang memiliki syarat tertentu sebagaimana ketentuan UUPM. Perkembangan penanaman modal dalam negeri di Indonesia dimulai sejak tahun 1968 dengan adanya Undang-Undang Nomor 6 Tahun 1968 tentang Penanaman Modal Dalam Negeri, sedangkan penanaman modal asing dimulai sejak Undang-Undang Nomor 1 Tahun 1967 tentang Penanaman Modal Asing. Perkembangan penanaman modal di Indonesia pada dasarnya mengalami peningkatan. Kendati demikian aplikasi penanaman modal khususnya penanaman modal asing di Indonesia belum memberikan hasil yang maksimal dan masih perlu diperbesar dan ditingkatkan. ${ }^{3}$ Hal ini dapat terlihat dari data BPS (Badan Pusat Statistik) 2014 bahwa jumlah penduduk miskin di Indonesia 28.513.57, jumlah pengangguran Indonesia mencapai 5.9 lebih tinggi dari vietnam, Malaysia, Singapura dan Thailand. Adapun realisasi investasi penanaman modal dalam negeri hingga tahun 2014 mencapai 156.126.30 miliar rupiah, sedangkan investasi penanaman modal asing hingga tahun 2014 mencapai 28529.70 juta US\$. ${ }^{4}$

\footnotetext{
${ }^{3}$ Aminuddin Ilmar, Hukum Penanaman Modal di Indonesia, Prenada Kencana Group, Jakarta, 2010, halaman 260. ${ }^{4}$ https://www.bps.go.id/linkTabelStatis/view/id/1880/diakses pada tanggal 17 Juni 2016
} 
Berdasarkan latar belakang tersebut diatas, maka dalam rangka pengajuan rencana penelitian disertasi ini penulis mengambil judul "Konsep Penanaman Modal Sebagai Upaya Mestimulasi Peningkatan Perekonomian Indonesia".

\subsection{Rumusan Masalah}

Berdasarkan uraian latar belakang yang dikemukakan di atas, maka penulis mengambil beberapa permasalahan yang sesuai dengan penulisan ini, yaitu:

1. Bagaimanakah perkembangan penanaman modal di Indonesia dari masa orde lama, orde baru dan orde revormasi?

2. Apa kendala dan solusi yang diberikan dalam meningkatkan penanaman modal di Indonesia?

\section{TINJAUAN PUSTAKA}

\section{Tinjauan Umum Penanaman Modal dan Manfaat Penanaman Modal}

\subsection{Pengertian Penanaman Modal}

Penanaman modal merupakan terjemahan kata "investment" berasal dari bahasa inggris yang diterjemahkan dalam bahasa Indonesia sebagai penanaman modal atau investasi. ${ }^{5}$ Dalam literatur hukum investasi, ada beberapa pendapat tentang pengertian investasi antara lain :

a. H. Salim HS dan Budi Sutrisno, mengemukanakan investasi adalah penanaman modal yang dilakukan oleh investor, baik investor asing maupun domestic dalam berbagai bidang usaha yang terbuka untuk investasi, dengan tujuan untuk memperoleh keuntungan. ${ }^{6}$

b. Ana Rokhmatussa'dyah dan Suratman menyatakan investasi adalah suatu kegiatan yang dilakukan baik oleh orang pribadi (natural person) maupun badan hukum (juridical person) dalam upaya untuk meningkatkan dan/atau mempertahankan nilai modalnya, baik yang berbentuk uang tunai (cash money), peralatan (equipment), asset tidak bergerak, hak atas kekayaan intelektual maupun keahlian. ${ }^{7}$

c. Hendrik Budi Untung mrnyatakan makna dari investasi atau penanaman modal adalah kegiatan yang dilakukan oleh seseorang atau badan hukum, menyisihkan sebagian pendapatannya agar dapat digunakan untuk melakukan sesuatu usaha dengan harapan pada suatu waktu tertentu akan mendapatkan hasil (keuntungan). ${ }^{8}$

\footnotetext{
${ }^{5}$ Rosyidah Rakhmawati, Hukum Penanaman Modal Indonesia, Bayumedia, Malang, 2003, halaman, 2-3.

${ }^{6}$ ibid, halaman 10.

${ }^{7}$ Ana Rokhmatussa' dyah dan Suratman, Hukum Investasi \& Pasar Modal, Sinar Grafika, Jakarta 2010, halaman. 3

${ }^{8}$ Hendrik Budi Untung, Hukum Investasi, Sinar Grafika, Jakarta, 2013, halaman 3.
} 
d. Pasal 1 angka 1 UU No. 25 Tahun 2007 tentang Penanaman Modal menyebutkan penanaman modal adalah segala bentuk kegiatan menanam modal baik oleh penanam modal dalam negeri maupun penanam modal asing untuk melakukan usaha di wilayah negara Republik Indonesia.

Berdasarkan berbagai pengertian tentang investasi sebagaimana di atas, maka dapat dikemukanakan pengertian investasi adalah suatu kegiatan penanaman modal yang dilakukan oleh penanam modal di wilayah Republik Indonesia guna memperoleh keuntungan.

Investasi merupakan kegiatan yang melibatkan banyak pihak didalamnya, yang memiliki fungsi dan peran masing-masing guna mempermudah proses dan tata cara investasi di suatu negara. Para pihak yang terlibat dalam proses penanaman investasi diantaranya adalah pemerintah pusat, pemerintah daerah, Badan Koordinasi Penanaman Modal (BKPM) dll. Kegiatan penanaman modal dapat dilakukan investor dengan beberapa macam diantaranya dengan mengambil bagian saham pada saat pendirian perseroan terbatas, membeli saham, serta melakukan cara lain sesuai dengan ketentuan peraturan perundang-undangan. Secara umum Undang-Undang Nomor 25 Tahun 2007 tentang penanaman Modal mengklasifikasikan investasi menjadi beberapa bentuk yaitu :

a. Penanaman modal langsung (direct investment) yaitu suatu kegiatan penanaman modal yang dilakukan secara langsung di suatu negara. Eksistensi penanaman modal secara langsung dengan melakukan kegiatannya dengan mendirikan perusahaan sendiri, maupun patungan (joint venture company) dengan perusaahaan dalam negeri, kerja sama operasi (joint operation scheme), konversi penyertaan utang menjadi saham pada perusahaan, serta memberikan bantuan teknis dan manajerial (technical and management assistance).

b. Penanaman modal tidak langsung (indirect investment) yaitu suatu kegiatan penanaman modal yang dilakukan secara tidak langsung di suatu negara. Penanaman modal tidak langsung ini dilakukan dengan pembelian surat berharga di pasar modal maupun pasar uang dengan membeli saham maupun obligasi serta valuta asing dengan prinsip mencari keuntungan dan penanam modal tidak ikut terlibat secara langsung dalam kegiatan pengelolaan usahanya.

Investasi berdasarkan sumber pembiayaannya sebagaimana ketentuan Undang-Undang No. 25 Tahun 2007 tentang Penanaman Modal, dapat dikatagorikan menjadi 2 yaitu penanaman modal dalam negeri dan penanam modal asing. Investasi ini didasarkan atas asal usul kewarganegaraan penanam modal.

a. Penanam modal dalam negeri yaitu perseorangan warga negara Indonesia, badan usaha Indonesia, negara Republik Indonesia, atau daerah yang melakukan penanaman modal di wilayah negara Republik Indonesia. Ada beberapa contoh penanam modal dalam negeri yang 
melakukan kegiatannya yakni UMKM, PT. Djarum, PT. Kereta Api Indonesia, PT. Bank Pembangunan Daerah Jawa Tengah.

b. Penanam modal asing yaitu perseorangan warga negara asing, badan usaha asing, dan/atau pemerintah asing yang melakukan penanaman modal di wilayah negara Republik Indonesia. Begitu pula ada beberapa contoh penanam modal asing yang melakukan kegiatannya yakni PT. Unilever Tbk, PT. Petronas Niaga Indonesia.

\subsection{Manfaat Penanaman Modal}

Upaya pemerintah dalam mengejar ketertinggalan pembangunan dengan negara-negara maju dalam bidang pembangunan diantaranya dengan menambah pinjaman luar negeri. Hal tersebut dirasa kurang maksimal sehingga pembangunan yang diharapkan berjalan lamban, oleh karena itu sebagai alternatif guna mendorong lajunya kemajuan pembangunan yang diharapkan, maka Indonesia masih mengandalkan penanam modal asing sebagai alternatif penyedia dana guna melaksanakan pembangunan multi bidang selain utang luar negeri. Harapan besar digantungkan pemerintah bagi penanam modal asing maupun untuk mempercayakan modalnya di Indonesia. Keberadaan penanam modal asing selain membawa modal yang besar juga dapat memberikan manfaat berupa transfer ilmu pengetahuan (transfer of know how) dan transfer teknologi (transfer of technology), keahlian dan keterampilan diberbagai bidang, menajemen perusahaan serta manajemen pemasaran. Selain itu penanam modal dalam negeri dan penanam modal asing akan meningkankan penyerapan jumlah tenaga kerja, penambahan devisa negara, menambah pendapatan asli daerah, meningkatkan daya saing perekonomian nasioan, serta memajukan dan memodernisasi dunia industri dalam negeri guna mewujudkan kesejahteraan masyarakat dan turut serta dalam pembangunan ekonomi nasional yang berkelanjutan dengan berlandaskan demokrasi ekonomi untuk mencapai tujuan bernegara.

Willian A. Fennel sebagaimana dikutip Huala Adolf menyatakan bahwa modal asing dapat memberikan modal kerja dan mendatangkan keahlian manajerial, ilmu pengetahuan, modal dan koneksi pasar. ${ }^{9}$ Hal ini tentunya sangat bermanfaaf bagi negara penerima penanaman modal guna meningkatkan eksport barang serta devisa negara. Selain itu negara penerima tidak perlu merisaukan atau menghadapi risiko manakala suat PMA yang masuk ke negerinya ternyata tidak mendapatkan untung dari modal yang ditanamkannya. ${ }^{10}$

\section{Teori Penaman Modal dan Syarat-Syarat untuk Menarik Modal Asing}

\subsection{Teori yang Mempengaruhi Penanaman Modal Asing}

\footnotetext{
${ }^{9}$ Huala Adolf, Perjanjian Penanaman Modal Dalam Hukum Perdagangan Internasional (WTO), Keni Media, Bandung, 2011, Halaman 5.

${ }^{10}$ Ibid.
} 
Ada beberapa yang menganalisis fakktor-faktor yang mempengaruhi penanaman modal asing yaitu teori Alan M Rugman, teori John Dunning dan teori David K. Eiteman teori Alan M. Rugman menyatakan bahwa penaanaman modal asing dipengaruhi oleh variabel lingkungan dan variabel internalisasi. Ada tiga jenis variabel lingkungan yang menjadi perhatian yaitu ekonomi, non ekonomi dan pemerintah. ${ }^{11}$ Bahwa faktor yang mempengaruhi terhadap penanaman modal asing yang mempercayakan modalnya di negara penerima modal (house country)berasal dari beberapa faktor yaitu ekonomi suatu negara, sosial budaya, serta kebijakan pemerintah.

Teori John During menyatakan bahwa faktor yang mempengaruhi penanaman modal asing melalui teori ancangan eklektis. Teori eklektis menetapkan suatu set yang terdiri dari tiga persyaratan yang diperlukan bila sebuah perusahaan akan berkecimpung dalam penanaman modal asing. Ketiga persyaratan itu meliputi keunggulan spesifik perusahaan, keunggulan internalisasi dan keunggulan spesifik negara. $^{12}$

Teori David K. Eiteman menyatakan bahwa ada tiga motif yang mendasari penanaman modal asing yaitu strategi, motif perilaku, motif ekonomi ${ }^{13}$

Apabila kita perhatikan saaat ini pemerintah Indonesia sangat membutuhkan penanam modal asing guna mengejar ketertinggalan kemajuan dalam segala bidang. Oleh karena itu dalam rangkameningkatkanpenanaman odal pemerintah emberikan berbagai kemudahan dan kelonggaran kepada penanam modal asing dengan memberikan kemudahan dalam memperoleh ijin, tersedianya tenaga kerja yang mumpuni, peta peluang investasi yang dapat dimaksimalkan oleh calon investor, peraturan perundang-undangan yang jelas.

\subsection{Pertimbangan dalam Rangka Penanaman Modal}

Dalam pelaksanaan penanaman modal perlu kiranya bagi penanam modal memilirkan risiko yang akan dipikul oleh penanam modal, hal ini dapat mengakibatkan berkurang bahkan hilangnya asset yang dimilikinya. Oleh karena itu para penanam modal wajar apabila memikirkan terlebih dahulu faktor-faktor penghambat serta potensi yang dimiliki suatu daerah sebelum melakukan penaanamann modal guna meminimalisir dampak kerugian akibat kesalahan dalam melakukan penanaman modal.

Biasanya ada beberapa faktor yang dipertimbangkan sebelum melakukan kegiatan penaanaman modal, antara lain seperti berikut ini:

a) Risiko menanam modal (Countri Risk)

b) Rentang Birokrasi

c) Transparansi dan kepastian hukum

\footnotetext{
${ }^{11}$ Salim HS dan Budi Sutrisno, Hukum Investasi di Indonsia, Rajawali Pers, Jakarta, 2014, halaman 161.

${ }^{12}$ Ibid, halaman 161-162.

${ }^{13}$ Ibid, halaman 163.
} 
d) Alih teknologi

e) Jaminan dan perlindungan investasi

f) Ketenagakerjaan

g) Ketersediaan infrastruktur

h) Keberadaan sumber daya alam

i) Akses pasar

j) Insentif perpajakan

k) Mekanisme penyelesaian sengketa yang efektif. ${ }^{14}$

Faktor-faktor kebijaksanaan juga memainkan peranan penting dalam usaha mempengaruhi arus investasi luar negeri langsung dalam membangun sumber-sumber. ${ }^{15}$ Hal ini tentunya terkait erat engan arah kebijakan investasi yang diambil oleh pemerintahpusat dalam mendorong arus penanaman modal di negaranya. Seluruh faktor - faktor diatas merupakan hal yang sering dipertimbangkan oleh penanam modal, oleh karena itu apabila pemerintah dapat menghilangkan atau setidak tidaknya meminimalisir faktor penghambat tersebut, maka dimungkinkan pada saatnya nanti pertumbuhan penanaman modal Indonesia akan menjadi raksasa dikawasan regional nahkan tidak menutup kemungkinan pula penanaman modal Indonesia akan menjadi pusat perekonomian dunia selayaknya China dan Amerika Serikat yang saat ini menguasai perekonomian dunia.

\section{TUJUAN DAN MANFAAT PENELITIAN}

\section{Tujuan Penelitian}

Adapun tujuan dari penelitian ini adalah sebagai berikut:

1. Untuk mendeskripsikan dan menjelaskan perkembangan penanaman modal dari masa orde lama, orde baru dan orde revormasi.

2. Untuk mendeskripsikan kendala serta solusi yang diberikan dalam meningkatkan penanaman modal di Indonesia.

\section{Manfaat Penelitian}

Manfaat yang diperoleh dari penelitian ini adalah:

1. Manfaat teoris

Hasil penelitian ini diharapkan dapat memberikan sumbangan pemikiran pada bidang ilmu hukum khususnya dalam bidang hukum penanaman modal.

2. Manfaat praktis

\footnotetext{
${ }^{14}$ Ida Bagus Rahmadi Supancana, Kerangka Hukum Kebijakan Investasi Langsung di Indonesia, Ghalian Indonesia, Bogor, 2006, halaman 4-8.

${ }^{15}$ J. Panglaykim, Investasi Langsung Jepang Di kawasan Asean, Andi Offset, Yogyakarta, 1984, halaman 31.
} 
Hasil penelitian ini diharapkan dapat menjadi masukan bagi pengambil kebijakan dalam upaya mestimulasi perkembangan penanaman modal di Indonesia .

\section{Metode Penelitian}

Penelitian merupakan suatu sarana pokok dalam mengembangkan ilmu pengetahuan dan teknologi. Hal ini disebabkan oleh karena penelitian bertujuan untuk mengungkapkan kebenaran secara sistematis, metodologis dan konsisten. Melalui proses penelitian tersebut diadakan analisa dan konstruksi terhadap data yang telah dikumpulkan dan diolah. ${ }^{16}$ Oleh karena itu penelitian merupakan sarana untuk memecahkan suatu permasalahan dengan menggunakan metode atau cara - cara tertentu sesuai dengan ilmu pengetahuan dan teknologi.

\section{Metode Pendekatan}

Penelitian Konsep Pertumbuhan Penanaman Modal Sebagai Upaya Mestimulasi Peningkatan Perekonomian Indonesia ini merupakan penelitian yuridis normatif. Sebagai penelitian hukum normatif, maka penelitian ini meliputi penelitian inventarisasi hukum positif, asas-asas hukum, penemuan hukum in concreto dan sinkronisasi hukum, ${ }^{17}$ sehingga pendekatan yang digunakan adalah pendekatan penal. ${ }^{18}$

\section{Spesifikasi Penelitian}

Spesifikasi penelitian yang digunakan dalam penelitian ini adalah deskriptif analitis yaitu menggambarkan peraturan perundang-undangan yang berlaku sebagai hukum positif dikaitkan dengan teori hukum dan praktek pelaksanaan hukum positif. Sebagai penelitian deskriptif analitis bertujuan menggambarkan secara tepat sifat-sifat suatu individu, keadaan, gejala atau kelompok tertentu atau untuk menentukan ada tidaknya hubungan antara suatu gejala dengan gejala lain dalam masyarakat. ${ }^{19}$

3. Teknik Pengumpulan Data

Data yang diperoleh melalui studi kepustakaan untuk mendapatkan konsepsi-konsepsi, teoriteori, pendapat-pendapat atau landasan teoritis yang berhubungan erat dengan permasalahan yang dibahas adalah data sekunder yang berupa bahan hukum primer, sekunder dan tersier.

a) Bahan hukum primer meliputi ;

- Undang-Undang Nomor 25 Tahun 2007 tentang Penanaman Modal;

- Peraturan Presiden Nomor 16 Tahun 2012 Tentang Rencana Umum Penanaman Modal;

- Peraturan Presiden Nomor 39 Tahun 2014 Tentang Penanaman Modal Tertutup, Terbuka, Terbuka Dengan Syarat;

\footnotetext{
${ }^{16}$ Soerjono Soekanto dan Sri mamudji, Penelitian Hukum Normatif Suatu Tinjauan Singkat, Rajawali Press, Jakarta, halaman 1.

${ }^{17}$ Jhony Ibrahim, Teori dan Metodologi Penelitian Hukum Normatif, Surabaya, Bayumedia, 2008, halaman 295.

${ }^{18}$ Roony Hanitijo Soemitro, Metodologi Penelitian Hukum dan Yurimetri, Cet III, Jakarta, Ghalia Indonesia, 1998, halaman 22-23.

${ }^{19} \mathrm{ibid}$, halaman 25 .
} 
b) Bahan hukum sekunder

Buku teks hukum,kamus hukum, jurnal hukum, pendapat para sarjana, komentar atas putusan hakim dan yurisprudensi.

c) Bahan hukum tersier

Bahan hukum yang memberikan petunjuk atau penjelasan atas bahan hukum primer dan sekunder berupa kamus, artikel, ensiklopedia.

4.Analisa Data

Analisis data yang dilakukan pada penelitian ini adalah analisa kualitatif, pada tahap ini data yang diperoleh disusun secara sistematis melakukan kajian dan telaah terhadap hasil pengolahan data yang dibantu dengan melakukan editing atau koding.

\section{PEMBAHASAN}

1. PERKEMBANGAN PENANAMAN MODAL DI INDONESIA DARI MASA ORDE LAMA, ORDE BARU, DAN ORDE REFORMASI

\subsection{Perkembangan Penanaman Modal Masa Orde Lama}

Indonesia pada tanggal 17 Agustus 1945 secara resmi menyatakan kemerdekaan dari penjajah, hal ini menandai bahwa bangsa Indonesia dapat menentunan nasibnya sendiri dalam bidang perekonomian. Pemerintah Indonesia di bawah Presiden Soekarno mengambil kebijakan untuk perekonomian Indonesia bertumpu pada penenaman modal dalam negeri semata dan penanaman modal asing enggan melakukan menanamkan modalnya mengingat pemerintah Indonesia masih mencari jati diri sebagai bangsa yang baru merdeka dan berkutat pada masalah penegakan hukum, pergulatan politik, serta penangkalan adanya aksi agresi militer Belanda yang mau masuk kembali untuk melakukan penjajahan di Indonesia. Selama 17 tahun berikutnya Indonesia hanya menjadi negara pengimport besar barang modal dan teknologi serta tidak satupun dalam bentuk penanaman modal asing secara langsung. ${ }^{20}$

Usaha pemerintahan Soekarno dalam pembangunan bidang perekonomian sudah dirancang sedemian rupa, akan tetapi mengahadapi berbagai hambatan dan rintangan dalam pelaksanaannya. Hambatan dalam pembangunan ekonomi pada masa orde lama juga dipengaruhi oleh sikap politik Indonesia, dimana pada masa pemerintahan Ir. Soekarno yang lebih condong pada sistim sosialis timur. Pemerintahan orde lama pada dasarnya telah melakukan berbagai kebijakan untuk mengundang penanam modal khususnya asing, dimana kepemilikan modalnya telah ditentukan pemerintah yaitu 51\% sahamnya harus dimiliki warga negara Indonesia dan sisanya milik asing. Kebijakan penanaman modal asing yang dilakukan Ir. Soekarno pada dasarnya bertujuan untuk melindungi penanam modal dalam negeri, mengurangi ketergantungan pihak asing serta bentuk nasionalisme bangsa Indonesia.

\footnotetext{
${ }^{20}$ Ibid, Hlm. 29-30
} 
Kebijakan Pemerintah Indonesia pada masa orde lama dengan adanya pembatasan kepemilikan saham asing maksimal 49\% mengakibatkan enggannya penanam modal asing untuk melakukan investasi di indonesia oleh karena itu pemerintah hanya mengandalkan penanaman modal dalam negeri serta sisasisa penanaman modal asing warisan Belanda seperti de javasche bank. Keberadaan penanam modal asing warisan Belanda sirna setelah kebijakan Ir. Soekarno yang melakukan nasionalisasi terhadap perusahaanperusahaan asing yang berada di Indonesia. Pertama kali kebijakan nasionalisasi perusahaan asing menimpa perusahaan Belanda pada tahun 1957 menyusul kemudian perusahaan Inggris dan Malaysia pada tahun 1963 sebagai imbas konvontrasi Indonesia dengan Malaysia serta perusahaan Amerika Serikat tahun 1965 sebagai akibat memihaknya Amerika Serikat kepada Malaysia dalam konvontrasi Indonesia melawan Malaysia.

Presiden Ir. Soekarno melalui Dekrit Presiden 5 Juli 1959 membubarkan sistem demokrasi parlementer sekaligus mencabut pemberlakuan UUDS 1950 sekaligus kembali ke UUD 1945. Pada saat itu Indonesia berada pada masa demokrasi terpimpin dimana presiden sebagai pusat pemegang kekuasaan sekaligus pusat pemikiran dan pengambilan kebijakan berada di presiden. Hal ini berimbas pada perekonomian yang juga bertumpu pada presiden, selanjutnya atas perintas presiden dibukalah proyekproyek pembangunan pabrik baja di Cilegon Banten, Superfosfat di Cilacap Jawa Tengah, Pembangkit Listrik tenaga Air (PLTA). Langkah gerak perekonomian Indonesia guncang kembali pada tahun 1965, dimana terjadi inflasi mencapai 20-30\% sebulan serta membengkaknya utang luar negeri Indonesia mencapai US\$2.400 juta.

1.2 Perkembangan Penanaman Modal Masa Orde Baru.

Perkembangan penanaman modal asing maupun dalam negeri para era orde baru dimulai pada tahun 1967 untuk penanaman modal asing dan 1968 untuk penanaman modal dalam negeri sampai tahun 1997. Perkembangan jumlah penanam modal asing maupun dalam negeri dapat disajikan sebagai berikut :

Perkembangan penanaman modal asing

\begin{tabular}{|c|c|c|c|}
\hline No & Tahun & Jumlah Persetujuan PMA & Jumlah Proyek \\
\hline 1 & 1967 & 210.6 miliar US\$ & 13 proyek \\
\hline 2 & 1968 & 256.4 miliar US\$ & 35 proyek \\
\hline 3 & 1969 & 127.5 miliar US\$ & 37 proyek \\
\hline 4 & 1970 & 170.2 miliar US\$ & 87 proyek \\
\hline 5 & 1971 & 310.4 miliar US\$ & 64 proyek \\
\hline 6 & 1972 & 171.7 miliar US\$ & 48 proyek \\
\hline 7 & 1973 & 338.5 miliar US\$ & 70 proyek \\
\hline
\end{tabular}




\begin{tabular}{|c|c|c|c|}
\hline 8 & 1974 & 565.6 miliar US\$ & 55 proyek \\
\hline 9 & 1975 & 1,153.9 miliar US\$ & 24 proyek \\
\hline 10 & 1976 & 251.2 miliar US\$ & 22 proyek \\
\hline 11 & 1977 & 187.3 miliar US\$ & 21 proyek \\
\hline 12 & 1978 & 237.0 miliar US\$ & 23 proyek \\
\hline 13 & 1979 & 237.0 miliar US\$ & 13 proyek \\
\hline 14 & 1980 & $1,081.3$ miliar US\$ & 21 proyek \\
\hline 15 & 1981 & 747.0 miliar US\$ & 24 proyek \\
\hline 16 & 1982 & 2.456.1 miliar US\$ & 32 proyek \\
\hline 17 & 1983 & 2,346.8 miliar US\$ & 46 proyek \\
\hline 18 & 1984 & 1,121.1 miliar US\$ & 23 proyek \\
\hline 19 & 1985 & 913.1 miliar US\$ & 46 proyek \\
\hline 20 & 1986 & $1,056.8$ miliar US\$ & 93 proyek \\
\hline 21 & 1987 & $1,918.1$ miliar US\$ & 141 proyek \\
\hline 22 & 1988 & 4,447.7 miliar US\$ & 147 proyek \\
\hline 23 & 1989 & 4,898.3 miliar US\$ & 308 proyek \\
\hline 24 & 1990 & 9,639.6 miliar US\$ & 444 proyek \\
\hline 25 & 1991 & $9,030.2$ miliar US\$ & 390 proyek \\
\hline 26 & 1992 & 10,466.1 miliar US\$ & 304 proyek \\
\hline 27 & 1993 & $8,153.8$ miliar US\$ & 330 proyek \\
\hline 28 & 1994 & 27,046.1 miliar US\$ & 444 proyek \\
\hline 29 & 1995 & 39,891.6 miliar US\$ & 782 proyek \\
\hline 30 & 1996 & 29,941.0 miliar US\$ & 947 proyek \\
\hline 31 & 1997 & $33,788.8$ miliar US\$ & 781 proyek \\
\hline \multicolumn{2}{|c|}{ Jumlah } & 190,631.7 miliar US\$ & 5,699 proyek \\
\hline
\end{tabular}

Sumber : BKPM

Lebih kanjut, perkembangan penanaman modal dalam negeri pada masa orde baru sejak tahun 1968 hingga 1997 dapat dilihat berdasarkan data sebagai berikut :

Perkembangan penanaman modal dalam negeri

\begin{tabular}{|c|c|c|c|}
\hline No. & Tahun & Nilai Persetujuan & Nilai Proyek \\
\hline 1 & 1968 & Rp. 38.6 miliar & 27 proyek \\
\hline 2 & 1969 & Rp. 36.6 miliar & 73 proyek \\
\hline
\end{tabular}




\begin{tabular}{|c|c|c|c|}
\hline 3 & 1970 & Rp. 1,296.5 miliar & 175 proyek \\
\hline 4 & 1971 & Rp. 218.3 miliar & 216 proyek \\
\hline 5 & 1972 & Rp. 184.9 miliar & 268 proyek \\
\hline 6 & 1973 & Rp. 492.4 miliar & 301 proyek \\
\hline 7 & 1974 & Rp. 214.4 miliar & 134 proyek \\
\hline 8 & 1975 & Rp. 160.1 miliar & 79 proyek \\
\hline 9 & 1976 & Rp. 401.6 miliar & 77 proyek \\
\hline 10 & 1977 & Rp. 490.2 miliar & 157 proyek \\
\hline 11 & 1978 & Rp. 751.4 miliar & 188 proyek \\
\hline 12 & 1979 & Rp. 682.4 miliar & 167 proyek \\
\hline 13 & 1980 & Rp. 1,589.9 triliun & 165 proyek \\
\hline 14 & 1981 & Rp. 2,384.9 triliun & 164 proyek \\
\hline 15 & 1982 & Rp. 3,767.1 triliun & 209 proyek \\
\hline 16 & 1983 & Rp. $6,574.2$ triliun & 341 proyek \\
\hline 17 & 1984 & Rp. 2,283.5 triliun & 145 proyek \\
\hline 18 & 1985 & Rp. 3,790,1 triliun & 245 proyek \\
\hline 19 & 1986 & Rp. 4,706.0 triliun & 315 proyek \\
\hline 20 & 1987 & Rp. 10,682.9 triliun & 571 proyek \\
\hline 21 & 1988 & Rp. $14,414.1$ triliun & 850 proyek \\
\hline 22 & 1989 & Rp. $19,639.5$ triliun & 868 proyek \\
\hline 23 & 1990 & Rp. 58,836.6 triliun & 1331 proyek \\
\hline 24 & 1991 & Rp. $41,210.8$ triliun & 808 proyek \\
\hline 25 & 1992 & Rp. 29,395.9 triliun & 422 proyek \\
\hline 26 & 1993 & Rp. 39,715.5 triliun & 547 proyek \\
\hline 27 & 1994 & Rp. 53,598.2 triliun & 825 proyek \\
\hline 28 & 1995 & Rp. 69,844.7 triliun & 793 proyek \\
\hline 29 & 1996 & Rp. 97,401.1 triliun & 807 proyek \\
\hline 30 & 1997 & Rp. $119,877.2$ triliun & 723 proyek \\
\hline \multicolumn{2}{|c|}{ Jumlah } & Rp. 580.384 .996 triliun & 11.991 proyek \\
\hline
\end{tabular}

Sumber : BKPM

Tahun 2007 merupakan tonggak sejarah baru bagi dunia penanaman modal di Indonesia, melalui Undang-Undang Nomor 40 Tahun 2007 tentang Penanaman Modal (selanjutnya disebut UUPM) pemerintahan Predisen Soesilo Bambang Yudhoyono menyamaratakan penanam modal baik dalam negeri 
maupun penanam modal asing serta tidak membeda-bedakan asal negara penanam modal. Pemerintah melalui UUPM memberikan berbagai fasilitas dan kemudahan untuk menarik investor agar dapat mempercayakan modalnya di Indonesia. Hal ini merupakan tantangan bagi penanam modal dalam negeri untuk bersaing secara terbuka dalam menghadapi serbuan investor asing. Oleh karena itu pemerintah telah mengeluarkan Peraturan Perintah Nomor 44 Tahun 2016 tentang Daftar Bidang Usaha Yang Tertutup Dan Daftar Bidang Usaha Yang Terbuka Dengan Persyaratan Di Bidang Penanaman Modal. Hal ini dilakukan tidak lain sebagai upaya untuk meningkatkan pertumbuhan ekonomi dan perkembangan penanaman modal di Indonesia denangan tetap memperhatikan kepentingan ekonomi nasional. Memasuki tahun kedua masa jabatannya, SBY hadir dengan terobosan pembangunannya berupa Master Plan Percepatan Perluasan Ekonomi Indonesia. Melalui langkah MP3EI diharapkan percepatan pembangunan ekonomi akan dapat menempatkan Indonesia sebagai negara maju pada tahun 2025 dengan pendapatan perkapita antara US\$ 14.250-US\$15.500 dengan nilai total perekonomian (PDB) berkisar antara US\$ 4,04,5 triliun. ${ }^{21}$ Perkembangan penanaman modal era reformasi dapat terlihat dalam tabel sebagai berikut : Perkembangan penanaman modal asing

\begin{tabular}{|c|c|c|c|}
\hline No. & Tahun & Nilai Persetujuan & Jumlah Proyek \\
\hline 1 & 1998 & 13,585 miliar US\$ & 1.034 proyek \\
\hline 2 & 1999 & 10,892, miliar US\$ & 1,174 proyek \\
\hline 3 & 2000 & 15,420 miliar US\$ & 1,524 proyek \\
\hline 4 & 2001 & 9,027 miliar US\$ & 1,317 proyek \\
\hline 5 & 2002 & 9,79 miliar US\$ & 1,151 proyek \\
\hline 6 & 2003 & 13,20 miliar US\$ & 1,024 proyek \\
\hline 7 & 2004 & 8,85 miliar US\$ & 969 proyek \\
\hline 8 & 2005 & 4,60 miliar US\$ & 909 proyek \\
\hline 9 & 2006 & 4,69 miliar US\$ & 485 proyek \\
\hline 10 & 2007 & 7,1 miliar US\$ & \\
\hline
\end{tabular}

\footnotetext{
${ }^{21}$ Hukum Online, Dinamika Investasi Dalam Rahmi Janed, Teori dan Kebijakan HukumInvestasi Langsung (Direct Investment),Kencana Predana Media Group, Jakarta, 2016, Hlm. 18.
} 


\begin{tabular}{|c|c|c|c|}
\hline 11 & 2008 & 14,2 miliar US\$ & 263 proyek \\
\hline 12 & 2009 & 10 miliar US\$ & 2,754 proyek \\
\hline 13 & 2010 & $16,214.8$ miliar US\$ & 3,076 proyek \\
\hline 14 & 2011 & $19,474.5$ miliar US\$ & 4,342 proyek \\
\hline 15 & 2012 & $24,564.7$ miliar US\$ & 4,579 proyek \\
\hline 16 & 2013 & $28,617.5$ miliar US\$ & 9,612 proyek \\
\hline 17 & 2014 & $28,529.7$ miliar US\$ & 8,885 proyek \\
\hline 18 & 2015 & $29,275.9$ miliar US\$ & 17,738 proyek \\
\hline 19 & 2016 & $28,964.1$ miliar US\$ & 25.321 proyek \\
\hline
\end{tabular}

Sumber : BKPM

Berdasarkan data tersebut jumlah persetujuan penanaman modal asing di Indonesia pada masa orde reformasi sebesar 296,991 miliar US\$ dengan jumlah proyek sebanyak 350.161. Tahun 2005 paling sedikit masuknya modal ke Indonesia dengan jumlah 4,60 miliar US\$ dengan jumlah proyek sebanyak 909 sedangkan tahun 2015 adalah tahun terbanyak masuknya modal asing ke Indonesia dengan mencatatkan 29,275.9 miliar US\$ dengan jumlah proyek sebanyak 17,738.

Lebih lanjut perkembangan penanaman modal dalam negeri pada era reformasi yang dimulai pada jaman Presiden BJ Habibie tahun 1998 hingga sekarang Presiden Joko Widodo dapat dilihat sebagaimana tabel di bawah ini :

Realisasi penanaman modal dalam negeri

\begin{tabular}{|c|c|c|c|}
\hline No. & Tahun & Nilai Persetujuan & Jumlah Proyek \\
\hline 1 & 1998 & Rp. 57.938 triliun & 320 proyek \\
\hline 2 & 1999 & Rp. 53.120 triliun & 228 proyek \\
\hline 3 & 2000 & Rp. 92,410 triliun & 355 proyek \\
\hline 4 & 2001 & Rp. 58,672 triliun & 249 proyek \\
\hline
\end{tabular}




\begin{tabular}{|c|c|c|c|}
\hline 5 & 2002 & Rp. 25,23 triliun & 188 proyek \\
\hline 6 & 2003 & Rp. 48,48 triliun & 181 proyek \\
\hline 7 & 2004 & Rp. 8,87 triliun & 145 proyek \\
\hline 8 & 2005 & Rp. 30,66 triliun & 214 proyek \\
\hline 9 & 2006 & Rp. 20,79 triliun & 145 proyek \\
\hline 10 & 2007 & Rp. 34,87 triliun & 305 proyek \\
\hline 11 & 2008 & Rp. 80,30 triliun & 90 proyek \\
\hline 12 & 2009 & Rp. 70,40 triliun & 150 proyek \\
\hline 13 & 2010 & Rp. 60,626 triliun & 875 proyek \\
\hline 14 & 2011 & Rp. 76,000 triliun & 1313 proyek \\
\hline 15 & 2012 & Rp. 92,182 triliun & 1210 proyek \\
\hline 16 & 2013 & Rp. 128,150 triliun & 2129 proyek \\
\hline 17 & 2014 & Rp. 156,126 triliun & 1652 proyek \\
\hline 18 & 2015 & Rp. 179,465 triliun & 5100 proyek \\
\hline 19 & 2016 & Rp. 216,230 triliun & 7511 proyek \\
\hline & & Rp. 1.510 .519 triliun & 22360 proyek \\
\hline
\end{tabular}

Sumber : BKPM 
Berdasarkan data tersebut investasi penanaman modal dalam negeri di Indonesia pada masa reformasi tercatat Rp. 1.510 .519 triliun dengan jumlah proyek sebanyak 22360. Tahun 2006 paling sedikit masuknya modal dalam negeri sebanyak Rp. 20,79 triliun dengan jumlah proyek sebanyak 145, sedangkan tahun 2016 adalah tahun terbanyak masuknya modal dalam negeri sebanyak Rp. 216,230 triliun triliun dengan jumlah proyek sebanyak 7511.

Perkembangan penanaman modal baik asing maupun dalam negeri yang terjadi selama orde lama, orde baru, dan orde reformasi di bawah Presiden Soekarno, Soeharto, BJ. Habibie, Abdurrahman Wahid, Megawati Soekarno Putri, Soesilo Bambang Yudhoyono dan Joko Widodo selama 71 tahun Indonesia Merdeka, apabila bibandingkan maka tahun 1997 adalah tahun terbanyak masuknya modal asing ke Indonesia dengan mencatatkan 33.788.8 miliar US\$ dengan jumlah proyek sebanyak 781 dan tahun 2016 adalah tahun terbanyak masuknya modal dalam negeri sebanyak Rp. 216,230 triliun dengan jumlah proyek sebanyak 7511.

\section{KENDALA DAN SOLUSI DALAM PENINGKATAN PENANAMAN MODAL DI INDONESIA}

\section{a. Kendala Dalam Penanaman Modal Di Indonesia}

Ada dua hambatan atau kendala yang dihadapi untuk mendatangkan investasi asing, sebagaimana diinventarisasi oleh BKPM yaitu kendala internal dan kendala eksternal. Hal hal yang termasuk dalam kendala internal adalah :

1. Kesulitan perusahaan mendapatkan lahan atau lokasi proyek yang sesuai;

2. Kesulitan memperoleh bahan baku;

3. Kesulitan dana/pembiayaan;

4. Kesulitan pemasaran;

5. Adanya sengketa atau perselisihan antara emegang saham. ${ }^{22}$

Lebih lanjut kendala eksternal dalam penanaman modal asing yng sering dikeluhkan oleh investor meliputi :

1. Faktor lingkungan bisnis baik nasional, regional, dan global yang tidak mendukung serta kurang menariknya insentif atau fasilitas investasi yang diberikan pemerintah

2. Masalah hukum

3. Keamanan maupun stabilitas politik yan merupakan factor eksternal ternyata menjadi factor penting bagi investor untuk menanamkan modal di Indonesia

\footnotetext{
${ }^{22}$ Salim HS dan Budi Sutrisno, Hukum Investasi di Indonesia, Rajawali press, Jakarta, 2014, Hlm. 97.
} 
4. Adanya peraturan daerah, keputusan menteri, undang-undang yang turut mendistorsi kegiatan penanaman modal. Setidaknya BKPM telah mengumpulkan perda 262 perda yang berkaitan dengan iklim investasi di Indonesia. Dari jumlah tersebut 206 perda berdasarkan kajian potensila menghambat investasi di Indonesia. Sebut saja semisalnya pajak penerangan jalan yang mewajibkan setiap pengguna listrik dan non PLN dikenakan pajak 5-10 persen dari nilai jual tenaga listrik ya dihitung berdasarkan kapasitas tersedia atau taksiran penggunaan listrik. Padalah begitu banyak industri yang menggunakan genset untuk menjalankan operasi pabrik.

5. Adanya Undang-Undang Nomor 41 Tahun 1999 tentang Kehutanan yang menimbulkan ketidakpastian dalam memanfaatkan areal hutan bagi industri pertambangan. ${ }^{23}$

Menurut Chatib Basri ada beberapa hambatan atau kendala dalam pelaksanaan penanaman modal di Indonesia yaitu :

1. Birokrasi yang kurang baik dalam pelayanan perijinan

2. Kenaikan upah buruh yang terus menerus disertai dengan tindakan kriminal, kekerasan dan penyanderaan.

3. Infrastruktur yang kurang memadai khususnya daerah-daerah di luar jawa yang sangat memprihatinkan. ${ }^{24}$

Berbagai hambatan penanaman modal di Indonesia sebagaimana tergambar di atas, merupakan permasalahan yang selama ini terjadi dan harus segera dicarikan solusi terbaik guna memberikan kepercayaan bagi investor agar mau mempercayakan investasi di Indonesia.

\subsection{Solusi Dalam Peningkatan Penanaman Modal Di Indonesia}

Perkembangan penanaman modal sejak era orde lama hingga orde reformasi kini telah mencapai usia 71 tahun. Kebijakan penanaman modal secara khusus diatur melalui Undang-Undang Nomor 1 Tahun 1967 tentang Penanaman Modal Asing dan Undang-Undang Nomor 7 Tahun 1968 tentang Penanaman Modal Dalam Negeri sebagaimana telah diganti dengan Undang-Undang Nomor 25 Tahun 2007 tentang Penanaman Modal. Pasca terbitnya UUPM Investasi di Indonesia mengalami perkembangan cukup baik selama 4 (empat) tahun terakhir. Namun demikian perkembangan penanaman modal asing maupun dalam negeri dirasa belum memberikan dampak yang signifikan dalam pembangunan perekonomian dan perkembangan investasi Indonesia yang disebabkan berbagai persoalan yang menghambat penanaman modal, sehingga para investor berpikir ulang ketika berniat melakukan penanaman modal di Indonesia.

\footnotetext{
${ }^{23}$ ibid

${ }^{24}$ http://www.kemenperin.go.id/artikel/4986/Singkirkan-Hambatan-Investasi diakses tanggal 9 Februari 2017
} 
Pada sisi lain keberadaan penanam modal asing di Indonesia sedikit banyak akan mempengaruhi kedaulatan negara dalam bidang perekonomian atas penggelolaan sumber daya alam serta hanya memberikan sedikit sumbangsih terhadap kemajuan bangsa dan menimbulkan banyak kerugian. Suara yang menentang kehadiran penanam modal asing mendaarkan argumentasinya pada tiga masalah utama yang menurut mereka pemerintah tidak pernah menghiraukannya yaitu :

a. Dalam usaha menarik penanam modal khususnya penanam modal asing, pemerintah terlalu bermurah hati melalui beberapa kebijakan yang dianggap sangat menguntungkan penanam modal seperti kebijakan keringanan pajak (tax holiday), pembebasan untuk jangka waktu tertentu yang sebetulnya pemerintah menanggung kerugian.

b. Adanya beban biaya penyesuaian (adjustment cost) yang harus ditanggung oleh industryindustri tradisional yang tentunya akan dapat berakibat pada ketidak mampuan industry tradisional untuk dapat bersaing, bukan hanya untuk local terlebih untuk eksport.

c. Kehadiran penanam modal khususnya penanam modal asing dianggap telah menciptakan ketergantungan kepada negara-negara maju yang pada akhirya melahirkan penjajahan ekonomi. $^{25}$

Namun demikian menurut hemat penulis bahwa penolakan sebagian pihak terhadap penanaman modal asing adalah kurang tepat, dimana saat ini pemerintah Indonesia serta penanam modal dalam negeri belum mampu berdikari dalam membangun perekonomian bangsa. Oleh karena itu masih layak apabila pemerintah Indonesia masih mengandalkan penanam modal asing sebagai jurus jitu dalam meningkatkan perkembangan penanaman modal di Indonesia.

Kebijakan pemerintah untuk membuka kran penanaman modal asing ternyata masih terdapat berbagai kendala dan hambatan, oleh karena itu pemerintah dalam mengahadapi hambatan penanaman modal harus segera mencari solusi terbaik, serta Badan Koordinasi Penanaman Modal (BKPM) yang ditunjuk pemerintah sebagai badan yang memiliki kewenangan menetapkan kebijaksanaan, penyelesaian persetujuan, penilaian pelaksanaan dan pengembangan penanaman modal harus segera berkoordinasi dalam rangka meningkatkan iklim investasi di Indonesia.

Pembaharuan hukum dalam bidang penanaman modal harus menjadi prioritas utama yang perlu dirumuskan dalam kerangka dasar serta kebijakan pengembangan penanaman modal dalam upaya menarik investasi Indonesia agar mampu bersaing dengan negara lain. Undang-Undang Nomor 40 Tahun 2007 tentang Penanaman Modal dirasa belum mampu untuk mengakomodir kebutuhan penanam modal diantanaya masa penggunaan Hak Guna Usaha yang mencapai maksimal 95 dirasa kurang memadai, khususnya bagi penanam modal yang bergerak dalam bidang pertambangan. Jika dibandingkan dengan

\footnotetext{
${ }^{25}$ Aminuddin Ilmar, Hukum Penanaman Modal Di Indonesia, Kencana Predana Media Group, Jakarta 2010, Hlm. 267-268.
} 
negara-negara lain khususnya negara tetanga seperti Malaysia, Thailand, Singapura, Filipin dan Vietnam ternyata perolehak Hak Guna Usaha (HGU) di negara ini lebih mudah dan kompetitif dari segi jangka waktu hingga 150 tahun lamanya. ${ }^{26}$

Pada sisi yang lain pemerintah juga wajib menghilangkan kendala serta hambatan teknis yang selama ini menjadi permasalahan dalam bidang penanaman modal yaitu :

a. Kepastian hukum sebagai tonggak awal dalam mendorong daya tarik investasi di Indonesia;

b. Penyediaan lahan bahan baku yang murah sesuai standart kebutuhan penanam modal yang tidak merusak lingkungan;

c. Terjaminnya siatuasi dan kondisi keamanan dalam negeri dan stabilitas politik di Indonesia;

d. Tersedianya tenaga kerja yang handal dan memadai serta upah buruh yang bersaing dan berkualitas;

e. Perijinan yang cepat, tidak adanya pungutan liar serta infrastruktur yang memadai;

f. Tersedianya pasar market bagi penanam modal untuk menjual hasil produknya.

\section{Simpulan}

1. Perkembangan penanaman modal era orde lama belum ada perkembangan yang berati, hal ini disebabkan masih terfokusnya orde lama mempertahankan kemerdekaan dari kembalinya Belanda untuk menjajah Indonesia. Pada era orde pencapaian terbaik PMA 1997 dengan 33.788 .8 miliar US\$ dan PMDN Rp. 119,877,2 triliun. Orde reformasi pencapaian terbaik PMA 2015 dengan mencatatkan 29,275.9 miliar US\$ dan PMDN 2016 sebanyak Rp. 216,230 triliun triliun. Oleh karena itu 1997 adalah tahun terbanyak masuknya modal asing ke Indonesia dengan dan 2016 tahun terbanyak masuknya modal dalam negeri selama 71 tahun Indonesia merdeka.

2. Kendala yang dihadapi Indonesia dalam penanaman modal datang dari internal maupun eksternal antara lain kesulitan dana/pembiayaan, kesulitan pemasaran, adanya sengketa atau perselisihan antara pemegang saham, masalah hukum, keamanan dan stabilitas politik. Solusi dalam penanaman dengan adaya kepastian hukum, penyediaan lahan bahan baku terjaminnya siatuasi dan kondisi keamanan dalam negeri dan stabilitas politik, tenaga kerja yang handal, perijinan yang cepat, hilangnya pungutan liar serta infrastruktur yang memadai, tersedianya pasar market bagi penanam modal.

\section{Saran}

1. Guna meningkatkan iklim penanaman modal di Indonesia, perlu sekiranya pemerintah bekerjasama dengan negara maju dengan menawarkan berbagai kelebihan, keunggulan, kemudahan

\footnotetext{
${ }^{26} \mathrm{Ibid}, \mathrm{Hlm} .265$.
} 
berinvestasi di Indonesia sekaligus memberdayakan penanam modal dalam negeri yang potensial serta UMKM sebagai motor penggerak roda perekonomian rakyat.

2. Meningkatkan semangat kewirausahaan dan menciptakan teknologi bagi masyarakat Indonesia sebagai embrio penanaman modal dalam negeri guna mengurangi tingkat ketergantungan kepada penanam modal asing yang selama ini terjadi di Indonesia.

\section{DAFTAR PUSTAKA}

\section{a. Buku-Buku}

Adolf, Huala. Perjanjian Penanaman Modal Dalam Hukum Perdagangan Internasional (WTO), Keni Media, Bandung, 2011.

Budi Untung, Hendrik. Hukum Investasi, Sinar Grafika, Jakarta, 2013.

HS Salim dan Sutrisno Budi, Hukum Investasi di Indonesia, Jakarta, Rajawali Pers, 2012.

Salim HS dan Budi Sutrisno, Hukum Investasi di Indonesia, Rajawali Press, Jakarta, Cetakan 4, 2014.

Ilmar, Aminuddin. Hukum Penanaman Modal di Indonesia, Prenada Kencana Group, Jakarta, 2010.

Kuripan, David.Aspek Hukum Penanaman Modal Asing Di Indonesia, Kencana Prenada Media Group, Jakarta, 2013.

Mertokusumo, Sudikno. Mengenal Hukum Suatu Pengantar, Liberty, Jogjakarta, 2003.

Panglaykim, J.Investasi Langsung Jepang Di kawasan Asean, Andi Offset, Yogyakarta, 1984

Rahmadi Supancana,Ida Bagus. Kerangka Hukum Kebijakan Investasi Langsung di Indonesia, Ghalian Indonesia, Bogor, 2006.

Rakhmawati Rosyidah, Hukum Penanaman Modal Indonesia, Malang, Bayumedia, 2003.

Rokhmatussa'dyah Ana dan Suratman, Hukum Investasi \& Pasar Modal, Jakarta, Sinar Grafika, 2010.

Soekanto, Soerjono dan Sri mamudji, Penelitian Hukum Normatif Suatu Tinjauan Singkat, Rajawali Press, Jakarta.

\section{b. Website}

https://www.bps.go.id/linkTabelStatis/view/id/1880diakses tanggal 17 Juni 2016

http://www.cnnindonesia.com/ekonomi/20161107152144-92-170923/bps-jumlah-pengangguran-diindonesia-menciut-530-ribu-orang/ diakses tanggal 8 Februari 2017.

https://www.bps.go.id/brs/view/id/1229 diakses tanggal 8 Februari 2017. 